Chapman University

Chapman University Digital Commons

Food Science Faculty Articles and Research

Science and Technology Faculty Articles and

Research

8-24-2017

\title{
Chlorogenic Acid Induced Colored Reactions and Their Effect on Carbonyls, Phenolic Content, and Antioxidant Capacity in Sunflower Butter Cookies
}

Sihui Liang

Chapman University

Lilian Were

ChapmanUniversity,were@chapman.edu

Follow this and additional works at: http://digitalcommons.chapman.edu/food_science_articles

Part of the Food Chemistry Commons, and the Other Food Science Commons

\section{Recommended Citation}

Liang, S., Were, L.M., 2018. Chlorogenic acid induced colored reactions and their effect on carbonyls, phenolic content, and antioxidant capacity in sunflower butter cookies. LWT - Food Science and Technology 87, 16-22. doi:10.1016/j.lwt.2017.08.069

This Article is brought to you for free and open access by the Science and Technology Faculty Articles and Research at Chapman University Digital Commons. It has been accepted for inclusion in Food Science Faculty Articles and Research by an authorized administrator of Chapman University

Digital Commons. For more information, please contact laughtin@chapman.edu. 


\section{Chlorogenic Acid Induced Colored Reactions and Their Effect on Carbonyls, Phenolic Content, and Antioxidant Capacity in Sunflower Butter Cookies}

Comments

NOTICE: this is the author's version of a work that was accepted for publication in LWT - Food Science and Technology. Changes resulting from the publishing process, such as peer review, editing, corrections, structural formatting, and other quality control mechanisms may not be reflected in this document. Changes may have been made to this work since it was submitted for publication. A definitive version was subsequently published in LWT - Food Science and Technology, volume 87, in 2017. DOI: 10.1016/j.lwt.2017.08.069

The Creative Commons license below applies only to this version of the article.

\section{Creative Commons License}

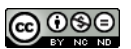

This work is licensed under a Creative Commons Attribution-Noncommercial-No Derivative Works 4.0 License.

\section{Copyright}

Elsevier 


\section{Accepted Manuscript}

Chlorogenic acid induced colored reactions and their effect on carbonyls, phenolic content, and antioxidant capacity in sunflower butter cookies

Sihui Liang, Lilian Were

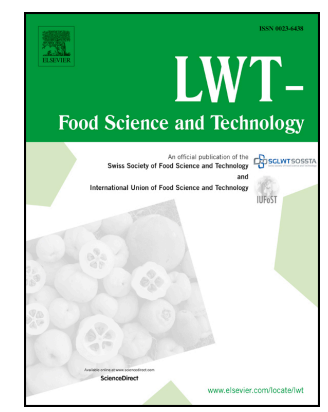

PII:

S0023-6438(17)30639-4

DOI:

10.1016/j.Iwt.2017.08.069

Reference: $\quad$ YFSTL 6491

To appear in: $\quad$ LWT - Food Science and Technology

Received Date: 12 June 2017

Revised Date: 9 August 2017

Accepted Date: 23 August 2017

Please cite this article as: Liang, S., Were, L., Chlorogenic acid induced colored reactions and their effect on carbonyls, phenolic content, and antioxidant capacity in sunflower butter cookies, LWT - Food Science and Technology (2017), doi: 10.1016/j.Iwt.2017.08.069.

This is a PDF file of an unedited manuscript that has been accepted for publication. As a service to our customers we are providing this early version of the manuscript. The manuscript will undergo copyediting, typesetting, and review of the resulting proof before it is published in its final form. Please note that during the production process errors may be discovered which could affect the content, and all legal disclaimers that apply to the journal pertain. 
1 Title

2 Chlorogenic acid induced colored reactions and their effect on carbonyls, phenolic content, and

3 antioxidant capacity in sunflower butter cookies

$4 \quad$ Name(s) of Author(s)

$5 \quad$ Sihui Liang and Lilian Were*

6 Author Affiliation(s)

7 Food Science Program, Schmid College of Science and Technology, Chapman University, One

8 University Drive, Orange, CA 92866, USA

$9 \quad *$ Contact information for Corresponding Author

10 Lilian Were, Ph.D.

11 Chapman University

12 Phone: 714-744-7895

13 Fax: 714-289-2041

14 E-mail: were@ chapman.edu 
Abstract:

The high chlorogenic acid (CGA) content of sunflower seeds causes a greening reaction in sunflower butter baked products which can deter application of sunflower butter as an allergen-free alternative to other plant and dairy based butters. This study focused on how greening intensity of sunflower butter cookies made with different sweeteners (maple, agave, corn syrups, honey and xylitol) affected greening, protein oxidation products, Folin and ABTS ${ }^{\circ+}$ radical scavenging ability. Cookies made with maple syrup and xylitol had higher $\mathrm{pH}$ and resulted in more greening. The dough made with agave syrup had highest total carbonyls caused by its highest reducing sugar content resulting in more Maillard reaction during dough preparation, while after baking cookies with highest greening (maple syrup) and highest reducing sugar (agave syrup) had higher carbonyls than other sweetener treatments. Cookies made with maple syrup and xylitol also had lower folin-ciocalteau reagent reducing capacity and tryptophan fluorescence. The greening reaction did not affect Schiff bases from oxidation and antioxidant capacity in cookies made with different sweeteners. Higher $\mathrm{pH}$ sweeteners thus enhanced greening intensity, tryptophan loss and lowered the total phenolic content after baking and storage, but did not influence the $\mathrm{ABTS}^{\circ+}$ capacity of sunflower butter cookies.

Keywords: Antioxidant capacity; carbonyls; chlorogenic acid; greening 


\section{Introduction}

Sunflower butter offers an alternative nut butter for people allergic to legume and tree nut butters. Compared to peanut and almond butter, sunflower seed butter offers additional nutritional benefits. It is an excellent source ( $\geq 20 \%$ of Daily Value) of minerals, such as phosphorus, magnesium, copper and selenium (FDA, 2013; Thomas \& Gebhardt, 2010), which are essential for building up bones and muscles, and are essential in formation of metabolic enzymes (NIH, 2017). Sunflower seed's lipids are 90g unsaturated fatty acids/100g total fatty acids with kernels containing 270-289 mg phyto-sterols/100g (Phillips, Ruggio, \& AshrafKhorassani, 2005; USDA, 2016).

In addition, sunflower butter is rich in phenolic compounds that have antioxidant health benefits (Olthof, Hollman, \& Katan, 2001). In particular, sunflower seeds have approximately $3.0 \mathrm{~g} / 100 \mathrm{~g}$ chlorogenic acid (CGA) of the $4.2 \mathrm{~g} / 100 \mathrm{~g}$ total phenolic content (dry matter) in kernels (Weisz, Kammerer, \& Carle, 2009). This high total phenolic content in sunflower seeds is almost 84 times higher than that in peanut butter, which has about $0.05 \mathrm{~g} / 100 \mathrm{~g}$ (Ma et al., 2013). Chlorogenic acid prevents lipid oxidation reactions (Budryn, Nebesny, Zyzelewicz, \& Oracz, 2014) by reducing free radical formation (Liang \& Kitts, 2016), inhibiting low-density lipoprotein (LDL) oxidation and DNA damage in vitro (Budryn et al., 2017; Olthof, Hollman, \& Katan, 2001). However, the high free CGA content induces a greening reaction in sunflower seed products which can hinder the application of sunflower butter in the bakery industry (Wildermuth, Young, \& Were, 2016). The greening reaction also consumes free CGA, protein and primary amino acids, and thus may affect the nutritional properties of sunflower butter bakery products. 
Different sweeteners have different sugar composition, $\mathrm{pH}$ and moisture (St-Pierre et al., 2014), which can influence the extent of Maillard and greening reactions (Devi \& Khatkar, 2016; Yabuta, Koizumi, Namiki, Hida, \& Namiki, 2001). Lower moisture, higher pH and reducing sugar cause more browning products (Pereyra Gonzales, Naranjo, Leiva, \& Malec, 2010). Besides color, the Maillard reaction can produce unhealthy products, for instance acrylamide, $\alpha$ dicarbonyls, and advanced glycation end products (AGEs) or healthy compounds such as antioxidant reductones (de Oliveira, dos Reis Coimbra, de Oliveira, Giraldo Zuniga, \& Garcia Rojas, 2016). The effect of the greening reaction on formation of compounds with nutritional effects warrants investigation. The higher moisture ingredients and higher $\mathrm{pH}$ in baked products using baking soda promote formation of green and blue pigments when free CGA and primary amino acids and/or proteins interact (Yabuta et al., 2001). This study focused on whether the greening reaction as a function of different sweeteners affected appearance in sunflower butter cookies in addition to antioxidant capacity, total phenolic content, and protein oxidation products (total carbonyl, tryptophan fluorescence and Schiff bases) before and after baking. Correlation between greening and changes in total phenols, antioxidant capacity and loss of tryptophan in cookies made with sunflower butter were determined.

\section{Materials and methods}

\subsection{Materials}

Sucrose $(\geq 99.5 \%)$, fructose $(\geq 99.0 \%)$, glucose $(\geq 99.5 \%)$, sodium carbonate $(\geq 99.0 \%)$, (+)-6-hydroxy-2,5,7,8-tetramethylchroman-2-carboxylic acid ( $\geq 98.0 \%)$, monosodium phosphate ( $\geq 99.0 \%)$, 2,4-dinitrophenylhydrazine $(97.0 \%)$, and disodium phosphate $(\geq 98.0 \%)$ were purchased from Sigma-Aldrich (St. Louis, MO. USA). HPLC-grade water and ethanol were 
obtained from Thermo Fisher Scientific (Huntington Beach, CA. USA). Folin-Ciocalteu reagent was obtained from MP Biochemicals (Santa Ana, CA. USA).

\subsection{Cookie formulation and experimental design}

Sunflower butter cookie dough treatments contaning one of four sweeteners (maple syrup/ UPC 096619955886, xylitol granules/ UPC 875002000033 diluted xylitol: water=8:2 (w:w), light corn syrup/ UPC: 761720051108, organic blue agave syrup/ UPC 012511204419 and honey/ UPC 073299000075) were prepared using the formulation presented in Fig. 1. The doughs were formed into disks of $4.5 \mathrm{~cm}$ diameter and $0.5 \pm 0.2 \mathrm{~cm}$ thickness and baked at 149 ${ }^{\circ} \mathrm{C}\left(300{ }^{\circ} \mathrm{F}\right)$ using a convection oven (JA12SL, Doyon, Inc. Saint-Côme-Linière, Canada) for 7 min. The baking temperature was monitored using a thermocouple thermometer (Nicety ${ }^{\circledR} \mathrm{K}$-type DT 1312). After baking, the cookies were stored uncovered at room temperature $\left(20 \pm 5^{\circ} \mathrm{C}\right)$ for $24 \mathrm{~h}$.

\subsection{Sugar composition}

Dough and cookie samples $(0.9 \pm 0.01 \mathrm{~g})$ with $30 \mathrm{~mL}$ HPLC water were homogenized (Multi-prep Homogenizer, PRO Scientific Inc., Oxford, CT. USA) at $1.3 \times 10^{3} * \mathrm{~g}$ for $1 \mathrm{~min}$. After centrifugation for $15 \mathrm{~min}$ at $0.3 \times 10^{3} * \mathrm{~g}$ and filtration using $0.45 \mu \mathrm{m}$ nylon membrane filters, the filtrates were stored at $4{ }^{\circ} \mathrm{C}$ for later use. Sucrose, glucose and fructose standards (0.3-2.8 $\mathrm{mg} / \mathrm{mL}$ ) were used to create a standard curve. The sugar content was quantified using a Shodex ${ }^{\circledR}$ Sugar SP0810 column (300 mm x 8 mm i.d., $8.0 \mathrm{~mm}$, Shodex, Colorado Springs, CO. USA) with a Shodex ${ }^{\circledR}$ Sugar SP-G 6B $(50 \mathrm{~mm}$ x $6 \mathrm{~mm}$ i.d $6.0 \mathrm{~mm})$ guard column. An Agilent HPLC 1100 series with a refractive index detector was used. The flow rate was $0.6 \mathrm{~mL} / \mathrm{min}$ with an isocratic elution with HPLC water at a run time of 25 min (Wang, Yagiz, Buran, Nunes, \& Gu, 2011). 
$\mathrm{pH}$ of sample mixtures prepared by dissolving $0.5 \mathrm{~g}$ of dough and cookies in $5 \mathrm{~mL}$ nano filtered water was measured according to AACCI method 02-52.01 (1999). After 1 min homogenization (Multi-prep Homogenizer, PRO Scientific Inc., Oxford, CT. USA) at speed of $1.3 \times 10^{3} *_{\mathrm{g}}$, mixtures were incubated for $1 \mathrm{~h}$, centrifuged (AccuSpin 1R-75003449, Thermo Fisher Scientific, Inc. CA. USA) at $9 \times 10^{3 *} \mathrm{~g}$ at $4{ }^{\circ} \mathrm{C}$ for $30 \mathrm{~min}$, before $\mathrm{pH}$ testing using a $\mathrm{pH}$ meter (Vernier Software \& Technology, OR. USA).

Internal greening intensity of cookies (lateral cut) was measured using a Hunter L*a*b* spectrophotometer (CM-2500d, Konica Minolta, Inc. Japan) where negative and positive $\mathrm{a}^{*}$ value represents greeness and redness respectively (Zhang, Chen, \& Wang, 2014).

\subsection{Carbonyl content}

Total carbonyl content was measured as outlined by Hawkins, Morgan, and Davies (2009) using 2,4-dinitrophenylhydrazine (DNPH) as the derivatization agent.

\subsection{Tryptophan and Schiff bases fluorescence}

Sweeteners $(0.12 \mathrm{~g})$ were dissolved in $20 \mathrm{~mL}$ nano filtered water to obtain the same sweetener concentration in cookies after baking. The sweetener solutions were placed into a convection oven for $7 \mathrm{~min}$ at $140{ }^{\circ} \mathrm{C}$ to account for tryptophan fluorescence from sweeteners alone. Dough and cookie samples $(0.3 \mathrm{~g})$ were dissolved in $10 \mathrm{~mL}$ nano filtered water. After homogenization, centrifugation and filtration $(0.45 \mu \mathrm{m}$ nylon syringe filter), the filtrates $(0.5 \mathrm{~mL})$ were diluted (1:10) using nano-filtered water. Tryptophan fluorescence intensity was measured at $\lambda_{\text {excitation }}=280 \mathrm{~nm}$ and $\lambda_{\text {emission }}=300-500 \mathrm{~nm}$, while Schiff bases produced from protein and lipid oxidation were measured at $\lambda_{\text {excitation }}=350 \mathrm{~nm}$ and $\lambda_{\text {emission }}=380-600 \mathrm{~nm}\left(\lambda_{\max }=475 \mathrm{~nm}\right)$, with a slit 
width of $5 \mathrm{~nm}$ using a Fluoromax-4 Spectrofluorometer (Horiba Scientific, CA. USA) as outlined by Utrera, Rodriguez-Carpena, Morcuende, and Estevez (2012).

2.7. Folin-Ciocalteu Reagent reducing and trolox equivalent antioxidant capacity (TEAC) assay

The supernatant for determination of Folin-Ciocalteu Reagent/FCR reducing capacity in sunflower butter cookies was prepared according to Yu, Nanguet, and Beta (2013). The sample supernatant $(0.2 \mathrm{~mL})$ and CGA standard solutions $(0.05-0.4 \mathrm{mg} / \mathrm{mL})$ were mixed with $1.5 \mathrm{~mL}$ 0.1 M Folin-Ciocalteu reagent and neutralized after $5 \mathrm{~min}$ using $1.5 \mathrm{~mL}$ of $6 \mathrm{~g} \mathrm{Na} 2 \mathrm{CO} 3: 100 \mathrm{~g}$ water before incubating for $30 \mathrm{~min}$ at $4{ }^{\circ} \mathrm{C}$. Sample solutions $(100 \mu \mathrm{L})$ were pipetted into a flat bottom microplate (Falcon®) for reading at $\lambda 760$ using a FLUOstar Omega Microplate Reader (BMG Labtech, Inc. Cary, NC. USA).

Antioxidant capacity of samples $(0.3 \mathrm{~g})$ dissolved in $30 \mathrm{~mL}$ ethanol/water $(30 / 70, \mathrm{v} / \mathrm{v})$ was also measured according to Zhang et al. (2014) using 0.16-0.67 mg/mL (+)-6-hydroxy2,5,7,8-tetramethylchroman-2-carboxylic acid as a standard.

\subsection{Statistics analysis}

The effect of 5 liquid sweeteners, storage time and their interactions were evaluated in a mixed model by a two-way analysis of variance (ANOVA): two fixed effects (sweeteners and storage time) as variables were repeated at 3 different time points. Where a significant effect of treatment was detected, the Student t-test was used to determine the levels of significance between dependent variables and two-way interactions of independent variables. All values were reported as the mean \pm standard deviation from duplicate batches of dough made on the same day. Differences were considered significant when $P<0.05$. Correlation between variables was calculated using Statistics Analysis Software (SAS Institute Inc. NC. USA). 
3. Results and discussion

\subsection{Sugar composition}

As expected (USDA, 2016), the sugar composition of dough and cookies presented in Table 1 showed that dough and cookies made with maple syrup had the most sucrose, followed by corn syrup, honey and agave syrup. Before baking there was no glucose and fructose in doughs made with maple syrup, but after baking, $0.5 \mathrm{mg} / \mathrm{g}$ fructose was measured, indicating some hydrolysis of sucrose occurred (Andrews, Godshall, \& Moore, 2002; Eggleston \& Amorim, 2006). Total sugars were higher in dough compared to the corresponding cookies. Decreased glucose and fructose after baking was attributed to reducing sugars being used up in the Maillard reaction (Martins, Jongen, \& Boekel, 2001). Sugars from the other carbohydrate containing ingredients (wheat flour and sunflower butter) in cookies were negligible as they were below detection limit in dough and cookies made with xylitol. Given that xylitol is a sugar alcohol, the source of the reducing sugars in all doughs was thus the liquid sweeteners, since flour and butter did not contribute to sugar content.

\subsection{Hunter $L^{*} a^{*} b^{*}$ and total carbonyls}

The greening intensity represented by Hunter $a^{*}$ value, showed that cookies made with maple syrup had the most greening (lowest $a^{*}$ value) among all other cookies at all time points tested (Table 2; $P<0.01$ ), which was due to higher $\mathrm{pH}$ and moisture content (Yabuta et al., 2001).

Total carbonyls content was similar in all doughs except the dough made with agave syrup, which had higher carbonyls than other doughs $(P<0.01$; Table 3$)$. These differences in carbonyl content in sunflower butter doughs were attributed to differences in reducing sugar and free amino groups content from different sweeteners, and their corresponding reactions (Yabuta et al., 2001; Yamaki, Kato, \& Kikugawa, 1992). The doughs made with agave syrup and honey 
had the highest reducing sugars. Agave syrup however had higher moisture compared to honey that may have also favored carbonyl product formation during dough preparation (Table 2; Mellado-Mojica \& Lopez, 2015; Yamaki et al., 1992).

The total carbonyls increased after baking, as heat induces protein and lipid oxidation in addition to accelerating browning and greening reactions (Dean, Fu, Stocker, \& Davies, 1997; Martins et al., 2001; Wildermuth et al., 2016). Lipid oxidation as a result of baking forms aldehydes and ketones such as malonaldehyde, hexanal and ketodienes, which could partially account for the higher carbonyls in cookies compared to dough in addition to carbonyls from Maillard reaction and protein oxidation (Dean et al., 1997; Martins et al., 2001; Yamaki et al., 1992). The total carbonyl content after baking was ranked as follows: cookies made with xylitol $\approx$ agave syrup>maple syrup>honey>corn syrup (Table 2 ), potentially due to more phenols and protein oxidation at higher $\mathrm{pH}$ in cookies made with xylitol and the higher reducing sugar content in cookies made with agave syrup (Damodaran, 2008). Given that xylitol is a nonreducing sugar and does not participate in Maillard browning, carbonyls in xylitol cookies were not from reducing sugars and Maillard reactions. In the presence of oxygen, amino acids and protein can easily react with free radicals to form carbonyl compounds (Dean et al., 1997). Cookies made with xylitol had the highest $\mathrm{pH}$. High $\mathrm{pH}$ can induce oxidation of polyphenols leading to oxidized products that may have enhanced greening reactions from oxidized polyphenols and protein interaction (Damodaran, 2008). Higher carbonyl content was found in cookies that were most green (those made with maple syrup and xylitol) than the cookies made with honey and corn syrup (Dean et al., 1997; Yabuta et al., 2001). The higher carbonyl content in cookies made with agave syrup (Table 3) was due to a balance between its moisture and reducing sugar content. The lowest $\mathrm{pH}$ of cookies was detected in cookies with agave syrup 
which also resulted in less greening and thus more free reactants/reducing sugars (Table 1 and 2). Greening and total carbonyl content was influenced by the various $\mathrm{pH}$ and moisture combinations, and could also be influenced by processing and storage history of the sugar syrups which were not determined in the current study.

\subsection{Schiff base fluorescence}

Schiff bases formed from oxidation were similar amongst dough and cookies made with different sweeteners. The Schiff bases however increased after baking (Fig. 2), which was due to the heat accelerating oxidation (Dean et al., 1997; Martins et al., 2001). Greening however had no effect on Schiff base formation.

\subsection{Tryptophan fluorescence}

The profile of fluorophores present in sweeteners showed a peak around $320 \mathrm{~nm}$ in honey, maple and agave syrups (Fig. 3a) that was absent in corn syrup and xylitol which could be from polyphenols (Papoti \& Tsimidou, 2009). A higher tryptophan (Trp) fluorescence intensity was detected in honey compared to other sweeteners after heating (Fig. 3a). Chen et al. (2017) quantified 1-3.6 mg/kg Trp using HPLC-FLD, and some Trp is thus inherently present in honey. Overall contribution of Trp fluorescence from the different sweetener ingredients was however neglible (Fig. 3a) compared to that in dough (Fig. 3b) and cookies (Fig. 3c-d). When UV-Vis spectra of the different dough and cookie solutions were compared, the highest absorbances at the maximum excitation wavelengths of tryptophan was the honey and lowest was maple and xylitol. Quenching of the tryptophan fluorescence in cookies with maple and xylitol was thus not from the sugars or inner filter effect (Gu \& Kenny, 2009), and was attributed to the greening reaction. 
The doughs made with different sweeteners had similar Trp fluorescence, which was higher than that of the corresponding cookies (Fig. 3b-c). The doughs' higher Trp fluorescence is from protein maintaining the native structure and less protein oxidation occuring before baking. After baking, Trp fluorescence in cookies was ranked as honey>corn syrup>agave syrup>xylitol>maple syrup (Fig.3). Cookies made with maple syrup had the largest decrease (40.3\% lower) in Trp fluorescence compared to corresponding doughs, while there was only a $14.0 \%$ and $20.2 \%$ trp decrease in cookies made with honey and corn syrup compared to their corresponding doughs. Trp fluorescence loss was attributed to Trp cross-linking with monomer CGA, Trp oxidation and Maillard reaction (Friedman, 1996; Utrera et al., 2012).

Potential decrease in surface hydrophobicity may have caused Trp loss and a $6 \mathrm{~nm}$ blue shift of Trp (Jiang, Xiong, Newman, \& Rentfrow, 2012) in cookies made with maple syrup and xylitol, possibly caused by dipole-dipole interactions under slightly higher $\mathrm{pH}$ conditions (Vivian \& Callis, 2001), which required less energy to quench protein. The blue shift in cookies made with xylitol due to the higher pH may have resulted in more Trp quenching (Ehrig, Muhoberac, Hurley, \& Bosron, 1992).

\subsection{Folin-Ciocalteu Reagent reducing and trolox equivalent antioxidant capacity (TEAC)}

There was no significant difference in FCR reducing capacity in dough as a function of the different sweeteners $(P>0.05$; Fig. 4.), which was attributed to sunflower butter being the major contributor to the total phenols measured. Folin-Ciocalteu reagent reducing capacity however increased after baking compared to dough, except for cookies made with xylitol. Increased FCR reducing capacity with heat has been noted by other investigators such as Zou, Yang, Zhang, He, and Yang (2015). Increased FCR reducing capacity from dough to cookies could be related to the reductones formed from Maillard reaction (Zilic et al., 2016), as the cookies made with higher 
reducing sugars (honey and agave syrup) had the highest FCR reducing capacity post-baking compared to cookies made with maple syrup and xylitol. Baking also may have increased the phenols' solubility by releasing the bound phenols (Zilic et al., 2016). The decrease in FCR reducing capacity after $24 \mathrm{~h}$ storage at $20-25^{\circ} \mathrm{C}$ could be due to loss of free CGA in greening and browning reactions (Martins et al., 2001; Yabuta et al., 2001).

When comparing the different treatments, cookies made with agave syrup had the highest total soluble phenols, from the higher reducing compounds (sugars and polyphenol) and the corresponding Maillard reaction (Everette et al., 2010). Lower soluble phenolics in cookies made with maple syrup and xylitol could be due to its higher $\mathrm{pH}$ consuming more CGA, the predominant phenol in sunflower butter, when reacted with amino groups to form green TBA pigments (Yabuta et al., 2001). Xylitol, a sugar alcohol does not undergo Maillard reaction resulting in the least browning (Table 1). Lowest FCR reducing capacity were in cookies made with xylitol (Borrelli, Esposito, Napolitano, Ritieni, \& Fogliano, 2004), and carbonyl containing CGA in cookies may have reacted with reactive amino acids such as proline, tryptophan to cause some browning, in addition to any hydrolysis products of CGA (quinic acid and caffeic acid) cross-linking with amino groups in cookies also contributing to the browning (Bongartz et al., 2016).

Antioxidant capacity is a balance between the loss of CGA antioxidants and formation of Maillard antioxidant products in cookies. Antioxidant capacity as assessed with $\mathrm{ABTS}^{\circ+}$ radical scavenging ability was highest in doughs and decreased after baking (Fig.4). The FCR reducing capacity was positively correlated with $\mathrm{ABTS}^{*+}$ radical scavenging ability in doughs $(\mathrm{r}=0.9516$, $P=0.01$ ), attributed to CGA's antioxidant capacity in doughs. In contrast to many studies where higher FCR reducing capacity is associated with higher $\mathrm{ABTS}^{\circ+}$ radical scavenging ability, our 
findings did not find a strong correlation between FCR reducing capacity and $\mathrm{ABTS}^{\circ+}$ radical scavenging ability $(\mathrm{r}=0.5538, P=0.33)$. Formation of Maillard reaction products and their associated antioxidant capacity did not compensate for the loss of phenolics/CGA in cookies with baking, as doughs had higher antioxidant capacity compared to cookies. The time/temperature combinations used maintained sufficient antioxidant capacity in the sunflower butter cookies, with the remaining CGA contributing significantly to the overall antioxidant capacity compared to Maillard reaction products (MRPs) formed during baking (DelgadoAndrade, Rufian-Henares, \& Morales, 2005). The lower antioxidant capacity after baking may have been caused by CGA-related greening reactions, which consumed free CGA during baking and storage (Yabuta et al., 2001), which could explain why cookies made with maple syrup had the lowest antioxidant capacity. Lower antioxidant capacity in cookies made with maple and xylitol could also be due to lower reducing compound content due to lower content of reducing sugars. The percent contribution of CGA compared to MRP to reducing ability in sunflower butter cookies warrants further investigation in addition to quantifying how MRP compounds such as dicarbonyls are affected (supplementary material).

\section{Conclusion}

Lower $\mathrm{pH}$ sweeteners with more reducing sugars, for instance, agave syrup and honey maintained more phenols, antioxidant capacity, and tryptophan than maple syrup, which has higher $\mathrm{pH}$ and low reducing sugar content. The study showed that higher $\mathrm{pH}$ and moisture sweeteners enhanced the greening reaction and resulted in lower total phenol, antioxidant capacity, and tryptophan fluorescence. The chemistry behind interactions between CGA, proteins and Maillard reaction products is largely unknown in sunflower based products. Further research could focus on determining specific advanced glycation products, such as pentosidine, $\mathrm{N}(\varepsilon)$ - 
carboxymethyl-lysine and fluorescent advanced glycation end products content to confirm the effect of greening reaction on formation of Maillard reaction products in food products where both reactions occur simultaneously.

\section{Acknowledgement}

The authors would like to thank Chapman University for financially supporting this research, and Han Lan Tran with the preliminary data collection.

\section{Conflicts of interest:}

None.

\section{References}

AACCI. (1999). AACC International Approved Methods, Method 02-52.01. Hydrogen-Ion Activity (pH) -- Electrometric Method. In 11th ed.). St. Paul, MN, U.S.A.

Andrews, L. S., Godshall, M. A., \& Moore, S. (2002). Sucrose degradation under model processing conditions. Journal of Food Science, 67, 1621-1624.

Bongartz, V., Brandt, L., Gehrmann, M. L., Zimmermann, B. F., Schulze-Kaysers, N., \& Schieber, A. (2016). Evidence for the Formation of Benzacridine Derivatives in AlkalineTreated Sunflower Meal and Model Solutions. Molecules, 21, 91.

Borrelli, R. C., Esposito, F., Napolitano, A., Ritieni, A., \& Fogliano, V. (2004). Characterization of a new potential functional ingredient: Coffee silverskin. Journal of Agricultural and Food Chemistry, 52, 1338-1343.

Budryn, G., Nebesny, E., Zyzelewicz, D., \& Oracz, J. (2014). Properties of model systems of sunflower oil and green coffee extract after heat treatment and storage. LWT-Food Science and Technology, 59, 467-478.

Budryn, G., Zaczynska, D., Zyzelewicz, D., Grzelczyk, J., Zdunczyk, Z., \& Juskiewicz, J. (2017). Influence of the Form of Administration of Chlorogenic Acids on Oxidative Stress Induced by High fat Diet in Rats. Plant Foods for Human Nutrition, 72, 184-191.

Chen, H., Jin, L., Chang, Q., Peng, T., Hu, X., Fan, C., et al. (2017). Discrimination of botanical origins for Chinese honey according to free amino acids content by high-performance liquid chromatography with fluorescence detection with chemometric approaches. Journal of the Science of Food and Agriculture, 97, 2042-2049.

de Oliveira, F. C., dos Reis Coimbra, J. S., de Oliveira, E. B., Giraldo Zuniga, A. D., \& Garcia Rojas, E. E. (2016). Food Protein-polysaccharide Conjugates Obtained via the Maillard Reaction: A Review. Critical Reviews in Food Science and Nutrition, 56, 1108-1125.

Damodaran, S. (2008). Fennema's Food Chemistry. In O. R. Fennema, S. Damodaran, \& K. L. Parkin (Eds.), Fennema's Food Chemistry (Fourth Edition ed., pp. 309). Boca Raton: CRC Press. 
Dean, R. T., Fu, S., Stocker, R., \& Davies, M. J. (1997). Biochemistry and pathology of radicalmediated protein oxidation. Biochemical Journal, 324, 1-18.

Delgado-Andrade, C., Rufian-Henares, J. A., \& Morales, F. J. (2005). Assessing the antioxidant activity of melanoidins from coffee brews by different antioxidant methods. Journal of Agricultural and Food Chemistry, 53(20), 7832-7836.

Devi, A., \& Khatkar, B. S. (2016). Physicochemical, rheological and functional properties of fats and oils in relation to cookie quality: a review. Journal of Food Science and TechnologyMysore, 53, 3633-3641.

Eggleston, G., \& Amorim, H. (2006). Reasons for the chemical destruction of sugars during the processing of sugarcane for raw sugar and fuel alcohol production. International Sugar Journal, 108, 271-279.

Ehrig, T., Muhoberac, B. B., Hurley, T. D., \& Bosron, W. F. (1992). Tryptophan Fluorescence Quenching by Alkaline $\mathrm{pH}$ and Ternary Complex-Formation in Human-Beta-1-Beta-1 and Horse EE Alcohol Dehydrogenases. Febs Letters, 300, 283-285.

Everette, J. D., Bryant, Q. M., Green, A. M., Abbey, Y. A., Wangila, G. W., \& Walker, R. B. (2010). Thorough Study of Reactivity of Various Compound Classes toward the FolinCiocalteu Reagent. Journal of Agricultural and Food Chemistry, 58, 8139-8144.

FDA. (2013). Guidance for Industry: A Food Labeling Guide (10. Appendix B: Additional $\begin{array}{llll}\text { Requirements for Claims). } & \end{array}$ https://www.fda.gov/Food/GuidanceRegulation/GuidanceDocumentsRegulatoryInformati on/LabelingNutrition/ucm064916.htm Accessed 02.04.17

Friedman, M. (1996). Food browning and its prevention: An overview. Journal of Agricultural and Food Chemistry, 44, 631-653.

Gu, Q., \& Kenny, J. E. (2009). Improvement of Inner Filter Effect Correction Based on Determination of Effective Geometric Parameters Using a Conventional Fluorimeter. Analytical Chemistry, 81(1), 420-426.

Hawkins, C. L., Morgan, P. E., \& Davies, M. J. (2009). Quantification of protein modification by oxidants. Free Radical Biology and Medicine, 46, 965-988.

Jiang, J., Xiong, Y. L., Newman, M. C., \& Rentfrow, G. K. (2012). Structure-modifying alkaline and acidic $\mathrm{pH}$-shifting processes promote film formation of soy proteins. Food Chemistry, 132, 1944-1950.

Kocadagli, T., \& Gokmen, V. (2014). Investigation of alpha-Dicarbonyl Compounds in Baby Foods by High-Performance Liquid Chromatography Coupled with Electrospray Ionization Mass Spectrometry. Journal of Agricultural and Food Chemistry, 62, 77147720.

Liang, N., \& Kitts, D. D. (2016). Role of Chlorogenic Acids in Controlling Oxidative and Inflammatory Stress Conditions. Nutrients, 8, 1-20.

Mellado-Mojica, E., \& Lopez, M. G. (2015). Identification, classification, and discrimination of agave syrups from natural sweeteners by infrared spectroscopy and HPAEC-PAD. Food Chemistry, 167, 349-357.

NIH/National Institutes of Health (2017). Dietary Supplement Fact Sheet. https://ods.od.nih.gov/factsheets/list-all/ Accessed 17.05.17

Olthof, M. R., Hollman, P. C. H., \& Katan, M. B. (2001). Chlorogenic acid and caffeic acid are absorbed in humans. Journal of Nutrition, 131, 66-71. 
Papoti, V. T., \& Tsimidou, M. Z. (2009). Looking through the qualities of a fluorimetric assay for the total phenol content estimation in virgin olive oil, olive fruit or leaf polar extract. Food Chemistry, 112, 246-252.

Pereyra Gonzales, A. S., Naranjo, G. B., Leiva, G. E., \& Malec, L. S. (2010). Maillard reaction kinetics in milk powder: Effect of water activity at mild temperatures. International Dairy Journal, 20, 40-45.

Phillips, K. M., Ruggio, D. M., \& Ashraf-Khorassani, M. (2005). Phytosterol composition of nuts and seeds commonly consumed in the United States. Journal of Agricultural and Food Chemistry, 53, 9436-9445.

St-Pierre, P., Pilon, G., Dumais, V., Dion, C., Dubois, M.-J., Dube, P., et al. (2014). Comparative analysis of maple syrup to other natural sweeteners and evaluation of their metabolic responses in healthy rats. Journal of Functional Foods, 11, 460-471.

Thomas, R., \& Gebhardt, S. E. (2010). Sunflower Seed Butter and Almond Butter as NutrientRich Alternatives to Peanut Butter. Journal of the American Dietetic Association, 110, A52.

USDA (2016). United States Department of Agriculture. Basic Report 12040, Seeds, sunflower seed butter, without salt. Maple syrup (UPC 096619955886), xylitol granules (UPC 875002000033), light corn syrup (UPC: 761720051108), organic blue agave syrup (UPC 012511204419), honey (UPC 073299000075). Agriculture Research Service. National Nutrient Database for Standard Reference Release 28.

Utrera, M., Rodriguez-Carpena, J. G., Morcuende, D., \& Estevez, M. (2012). Formation of Lysine-Derived Oxidation Products and Loss of Tryptophan during Processing of Porcine Patties with Added Avocado Byproducts. Journal of Agricultural and Food Chemistry, 60, 3917-3926.

Vivian, J. T., \& Callis, P. R. (2001). Mechanisms of tryptophan fluorescence shifts in proteins. Biophysical Journal, 80, 2093-2109.

Wang, W., Yagiz, Y., Buran, T. J., Nunes, C. d. N., \& Gu, L. (2011). Phytochemicals from berries and grapes inhibited the formation of advanced glycation end-products by scavenging reactive carbonyls. Food Research International, 44, 2666-2673.

Weisz, G. M., Kammerer, D. R., \& Carle, R. (2009). Identification and quantification of phenolic compounds from sunflower (Helianthus annuus L.) kernels and shells by HPLCDAD/ESI-MS ${ }^{\mathrm{n}}$. Food Chemistry, 115, 758-765.

Wildermuth, S. R., Young, E. E., \& Were, L. M. (2016). Chlorogenic Acid Oxidation and Its Reaction with Sunflower Proteins to Form Green-Colored Complexes. Comprehensive Reviews in Food Science and Food Safety, 15, 829-843.

Yabuta, G., Koizumi, Y., Namiki, K., Hida, M., \& Namiki, M. (2001). Structure of green pigment formed by the reaction of caffeic acid esters (or chlorogenic acid) with a primary amino compound. Bioscience Biotechnology and Biochemistry, 65, 2121-2130.

Yamaki, S., Kato, T., \& Kikugawa, K. (1992). Characteristics of Fluorescence Formed by the Reaction of Proteins with Unsaturated Aldehydes, Possible Degradation Products of Lipid Radicals. Chemical \& Pharmaceutical Bulletin, 40, 2138-2142.

Yu, L., Nanguet, A. L., \& Beta, T. (2013). Comparison of Antioxidant Properties of Refined and Whole Wheat Flour and Bread. Antioxidants (Basel, Switzerland), 2, 370-383.

Zhang, X., Chen, F., \& Wang, M. (2014). Antioxidant and Antiglycation Activity of Selected Dietary Polyphenols in a Cookie Model. Journal of Agricultural and Food Chemistry, 62, 1643-1648. 
406

407

408

409

410

411

412

Zilic, S., Kocadagli, T., Vancetovic, J., \& Gokmen, V. (2016). Effects of baking conditions and dough formulations on phenolic compound stability, antioxidant capacity and color of cookies made from anthocyanin-rich corn flour. LWT-Food Science and Technology, 65, 597-603.

Zou, Y. P., Yang, M., Zhang, G., He, H., \& Yang, T. K. (2015). Antioxidant Activities and Phenolic Compositions of Wheat Germ as Affected by the Roasting Process. Journal of the American Oil Chemists Society, 92, 1303-1312. 


\section{Table}

Table 1. Sugar composition of doughs and cookies made with different sweeteners.

\begin{tabular}{|c|c|c|c|c|c|c|c|c|}
\hline & \multicolumn{3}{|c|}{ Sugar composition $(\mathrm{mg} / \mathrm{g}$, wb) in dough } & \multirow[b]{2}{*}{ Total } & \multicolumn{4}{|c|}{ Sugar composition $(\mathrm{mg} / \mathrm{g}, \mathrm{wb})$ in cookies after $0.25 \mathrm{~h}$} \\
\hline & Sucrose & Glucose & Fructose & & Sucrose & Glucose & Fructose & Total \\
\hline Maple syrup & $13.76 \pm 0.002^{\mathrm{a}}$ & bdl & bdl & 13.76 & $13.02 \pm 0.001^{\mathrm{a}}$ & bdl & $0.50 \pm 0.000^{\mathrm{d}}$ & 13.37 \\
\hline Xylitol & bdl & bdl & bdl & bdl & bdl & bdl & bdl & bdl \\
\hline Corn syrup & $6.77 \pm 0.000^{\mathrm{b}}$ & $2.55 \pm 0.000^{\mathrm{b}}$ & $0.16 \pm 0.000^{\mathrm{c}}$ & 9.47 & $4.16 \pm 0.000^{\mathrm{b}}$ & $1.83 \pm 0.000^{\mathrm{b}}$ & $0.63 \pm 0.001^{\mathrm{c}}$ & 6.62 \\
\hline Agave syrup & $0.68 \pm 0.001^{\mathrm{d}}$ & $0.11 \pm 0.000^{\mathrm{c}}$ & $15.22 \pm 0.001^{\mathrm{a}}$ & 16.00 & $0.53 \pm 0.002^{\mathrm{d}}$ & $0.28 \pm 0.002^{\mathrm{c}}$ & $10.67 \pm 0.000^{\mathrm{a}}$ & 11.84 \\
\hline Honey & $1.76 \pm 0.002^{\mathrm{c}}$ & $6.88 \pm 0.001^{\mathrm{a}}$ & $7.16 \pm 0.000^{b}$ & 15.79 & $1.31 \pm 0.000^{\mathrm{c}}$ & $6.27 \pm 0.001^{\mathrm{a}}$ & $7.36 \pm 0.002^{b}$ & 14.93 \\
\hline
\end{tabular}

Values are the average of four replicates \pm standard deviation. Same letters in each column are not significantly different $(P>0.05)$ bdl refers to below detection limit. 
Table 2. Photos representing relationship between greening of cookies as a function of storage time and sweeteners differing in moisture, $\mathrm{pH}$ and time.

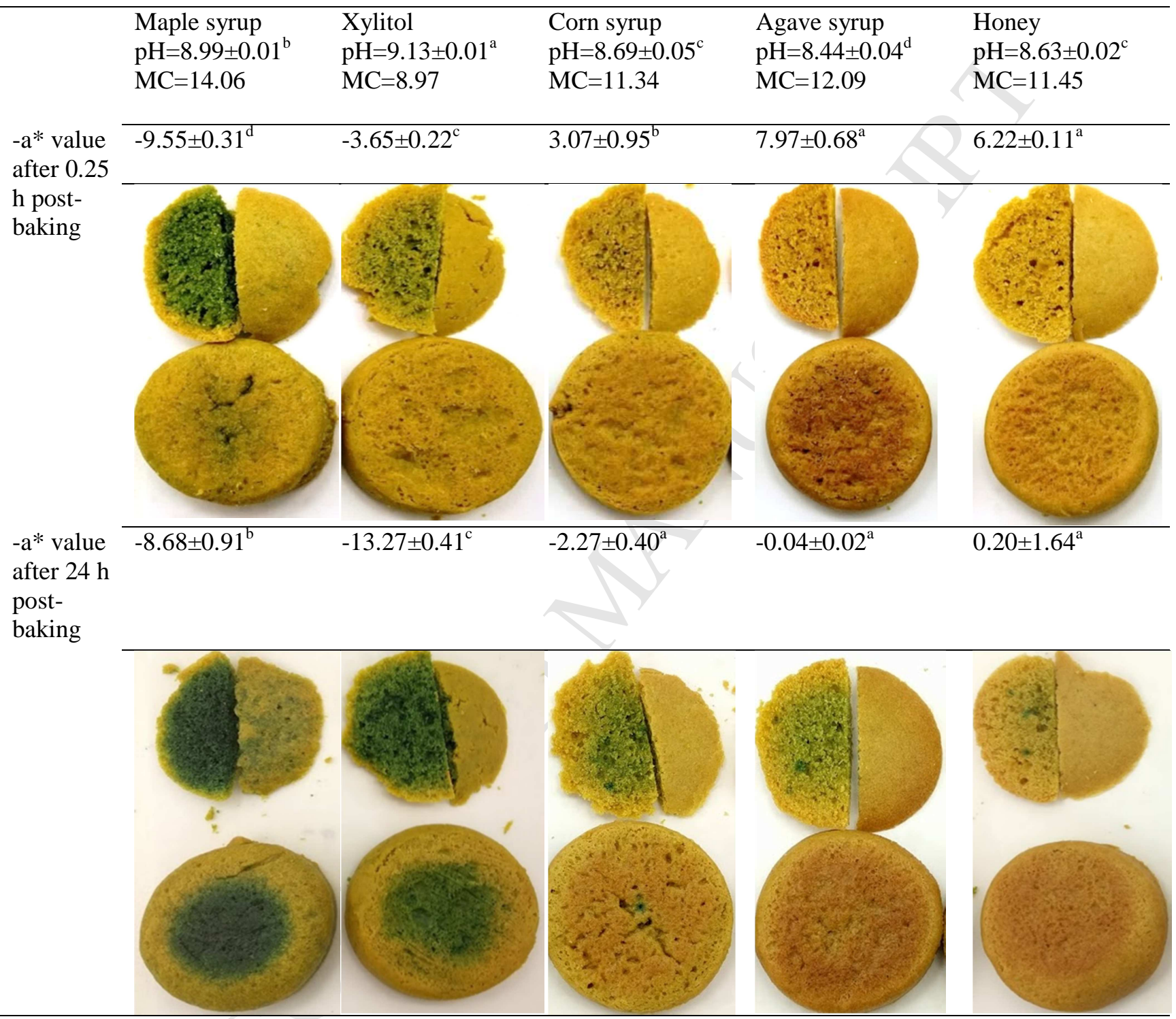

$\mathrm{MC}$ is $\%$ moisture content of cookies, $\mathrm{pH}$ was measured in $10 \%$ cookie solution while Internal greening intensity (Hunter $a^{*}$ value) was averaged from two cookies after placing the spectrophotometer probe in the middle of the cookies after a lateral cut.

Same letters in each row are not significantly different $(P>0.05)$. 
Table 3. Carbonyl compounds (nmol/mg) ${ }^{1}$ of dough and cookies using 2,4dinitrophenylhydrazine (DNPH) derivatization.

\begin{tabular}{lclllc}
\hline \multicolumn{1}{c}{ Treatment } & Maple syrup & Xylitol & Corn syrup & Agave syrup & Honey \\
\hline Dough & $0.16 \pm 0.00^{\mathrm{b}}$ & $0.01 \pm 0.00^{\mathrm{b}}$ & $0.37 \pm 0.00^{\mathrm{b}}$ & $2.29 \pm 0.67^{\mathrm{a}}$ & $0.56 \pm 0.11^{\mathrm{b}}$ \\
Cookie $(0.25 \mathrm{~h})$ & $7.61 \pm 0.21^{\mathrm{b}}$ & $14.66 \pm 3.01^{\mathrm{a}}$ & $4.40 \pm 0.05^{\mathrm{d}}$ & $12.29 \pm 1.51^{\mathrm{a}}$ & $5.82 \pm 0.52^{\mathrm{c}}$ \\
Cookie $(24 \mathrm{~h})$ & $4.77 \pm 1.05^{\mathrm{a}}$ & $3.72 \pm 0.35^{\mathrm{a}}$ & $3.31 \pm 0.47^{\mathrm{a}}$ & $5.36 \pm 0.12^{\mathrm{a}}$ & $4.14 \pm 0.02^{\mathrm{a}}$ \\
\hline
\end{tabular}

${ }^{\mathrm{T}}$ Values are the average of four replicates \pm standard deviation, same letter in each row means values were not significantly different $(P>0.05)$ 
1

2

\section{Figure Captions}

Fig. 1. Sunflower butter cookie formulation

Fig. 2. Schiff base fluorescence intensity at $\lambda_{\max }=475 \mathrm{~nm}\left(\lambda_{\mathrm{ex}}=350 \mathrm{~nm}\right.$ and $\left.\lambda_{\mathrm{em}}=380-600 \mathrm{~nm}\right)$ between doughs and cookies made with different sweeteners 0.25 and $24 \mathrm{~h}$ post-baking; A.U. refers arbitrary unit. Error bars represent standard deviations of means from two cookies. $\square$ Maple syrup $\square$ XylitolIII Corn syrup Agave syrup $\square$ Honey

Fig. 3. Tryptophan intensity spectrum of sweeteners, doughs and cookies as a function of time. Black line ---- refers to $\lambda_{\max }=356 \mathrm{~nm}$, blue line — indicates $6 \mathrm{~nm}$ blue shift of cookies made with maple syrup and xylitol, $\lambda_{\max }=350 \mathrm{~nm}$. Lines are means from two replicates.

\section{— Maple syrup ..... Xylitol - - Corn syrup -...... Agave syrup - - - Honey}

Fig. 4. Folin-Ciocalteu reagent reducing capacity/FRC (primary y-axis, bar graph) and trolox equivalent antioxidant capacity/TEAC (secondary y-axis, line scatter graph) of doughs and cookies made with different sweeteners.

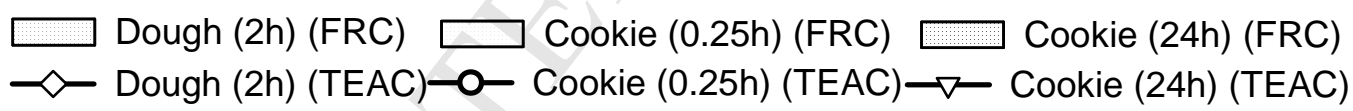

Error bars represent standard deviations of means from two cookies.

Same lettering above bars refers to treatments that were not significantly different $(P>0.05)$ at the different time points 
Figure

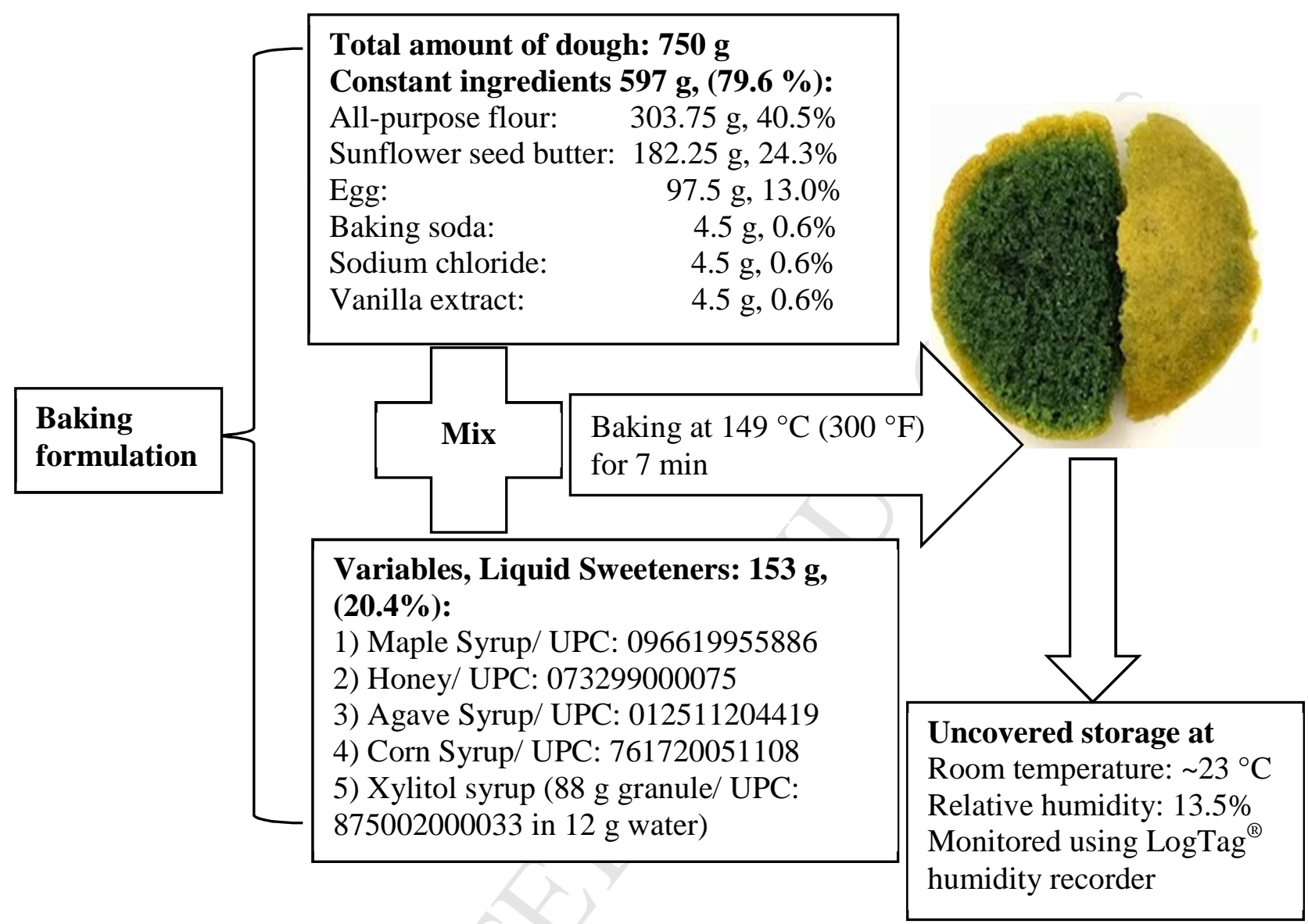

Fig. 1. 


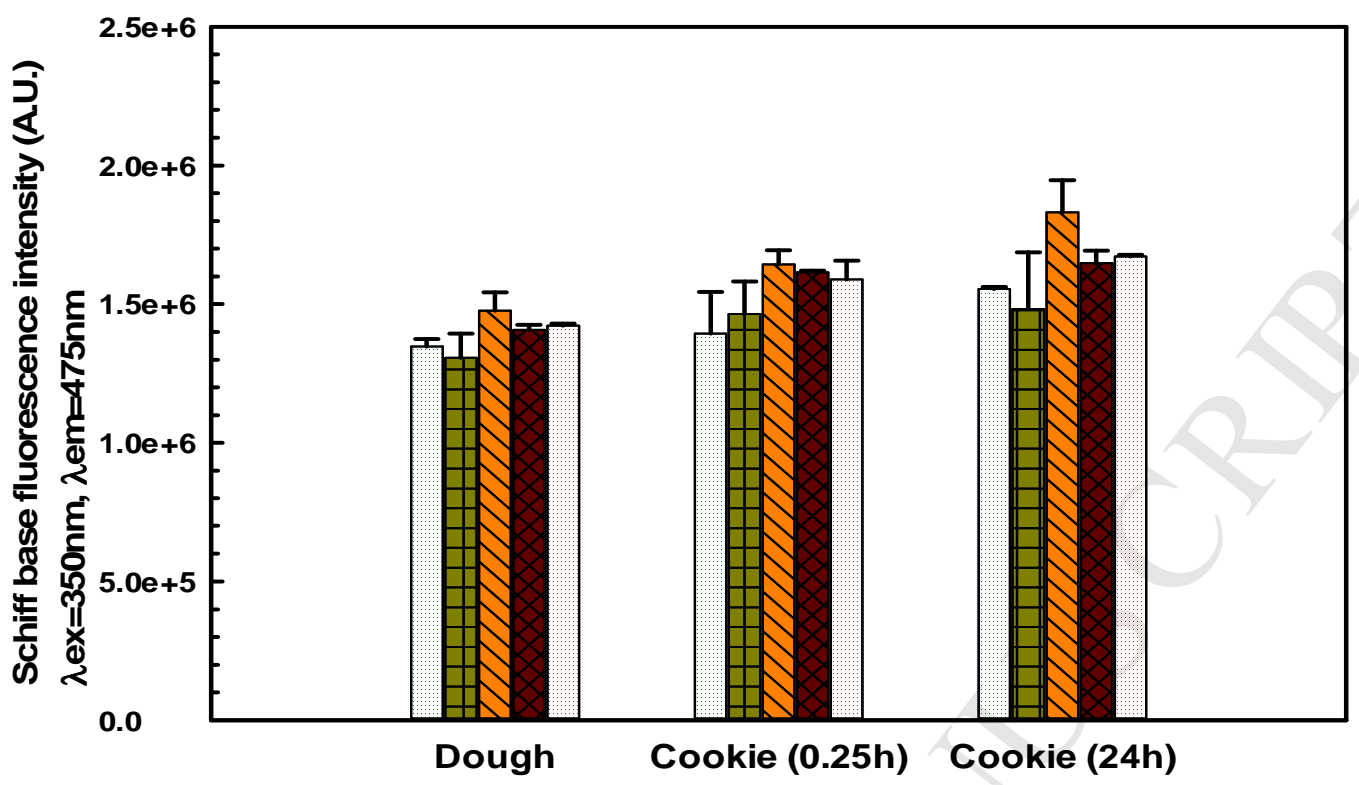

Fig. 2. 
a) Sweeteners

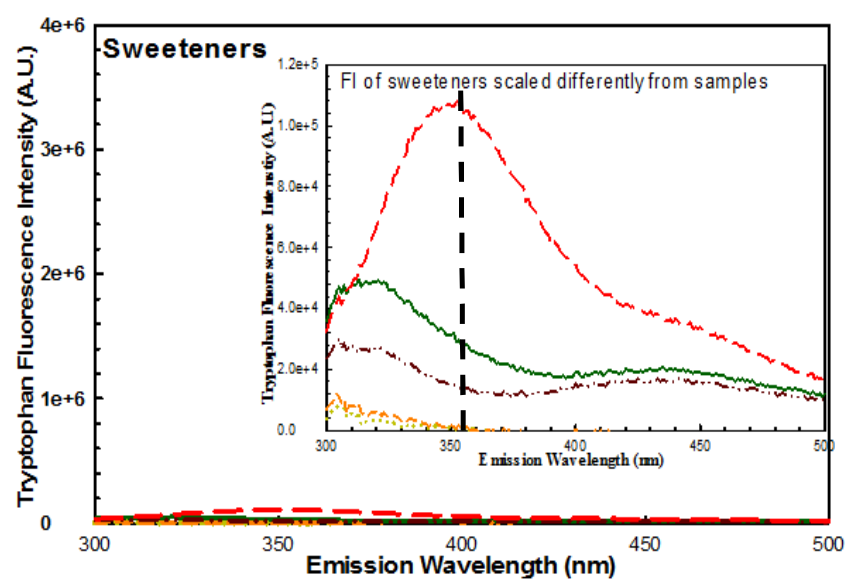

c) Cookies after $0.25 \mathrm{~h}$ of uncovered storage

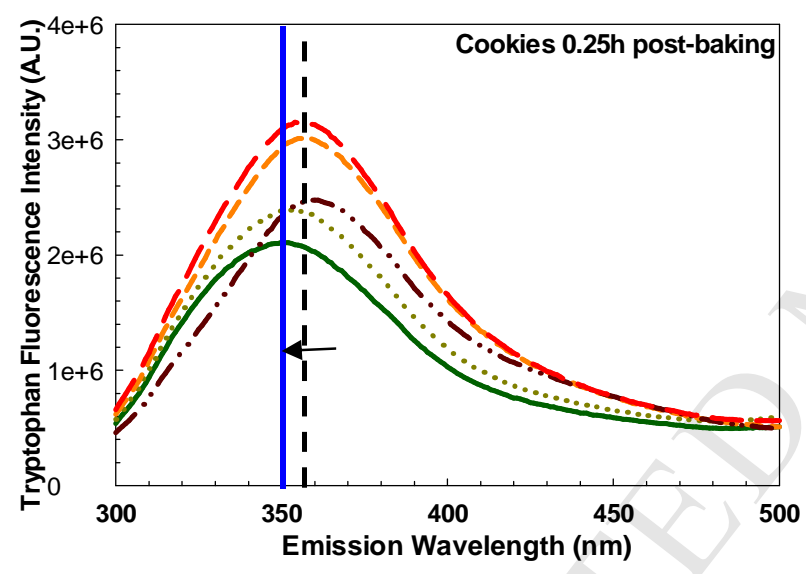

b) Dough

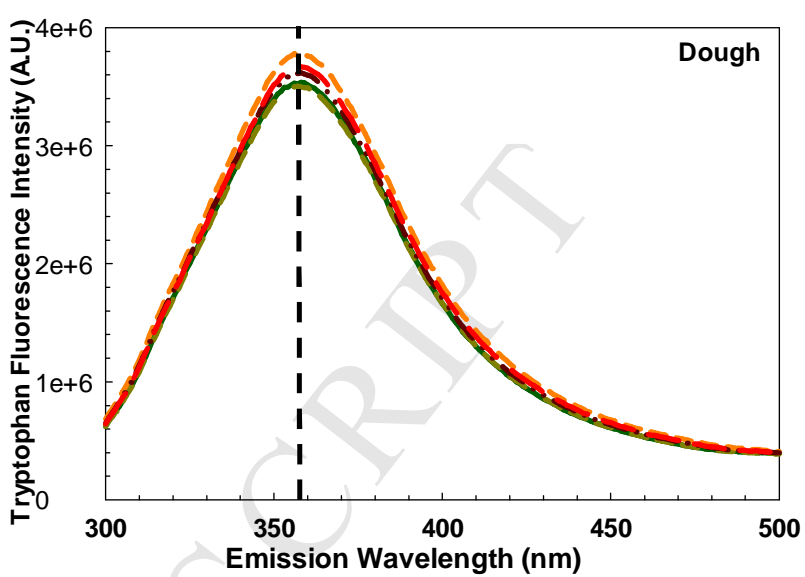

d) Cookies after 24h of uncovered storage

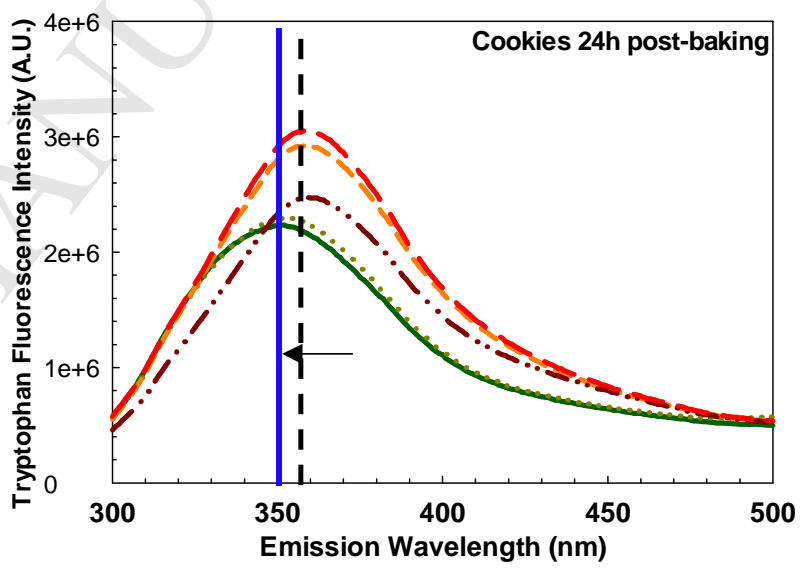

Fig. 3. 


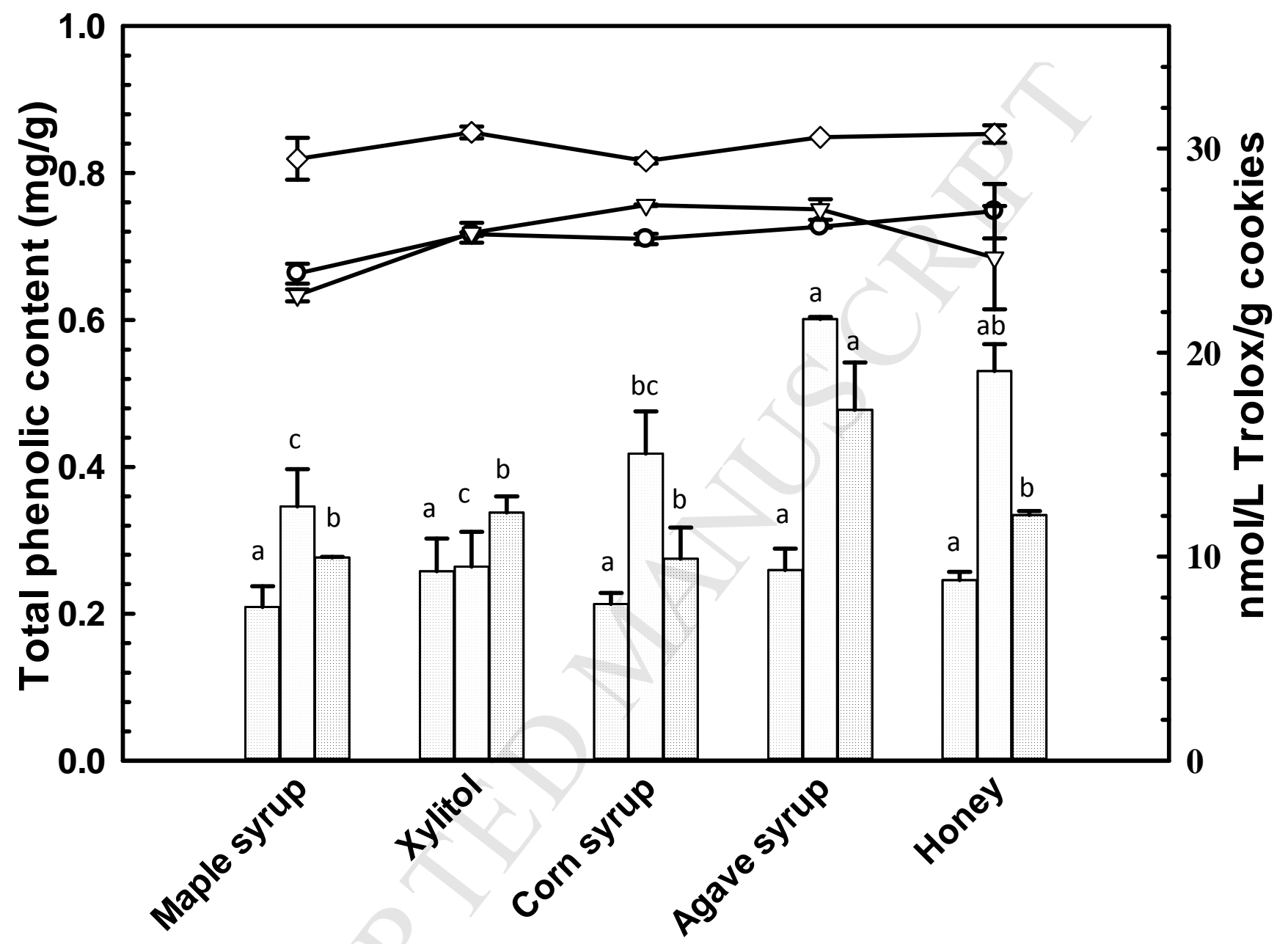

Fig. 4. 


\section{Highlights:}

- Chlorogenic acid is a reactant in both greening and browning reactions

- Greening reaction lowered tryptophan fluorescence and total phenols

- Greening reaction did not affect the antioxidant capacity in cookies

- Schiff bases from oxidation were not affected by sweeteners and greening 